\title{
Article \\ Growth of Basil (Ocimum basilicum) in Aeroponics, DRF, and Raft Systems with Effluents of African Catfish (Clarias gariepinus) in Decoupled Aquaponics (s.s.)
}

\author{
Johannes Pasch ${ }^{1, *, \dagger}$, Samuel Appelbaum ${ }^{2}$, Harry Wilhelm Palm ${ }^{1}\left[\mathbb{D}\right.$ and Ulrich Knaus ${ }^{1,+}$ \\ 1 Department of Aquaculture and Sea-Ranching, Faculty of Agricultural and Environmental Science, \\ University of Rostock, D-18059 Rostock, Germany; harry.palm@uni-rostock.de (H.W.P.); \\ ulrich.knaus@uni-rostock.de (U.K.) \\ 2 French Associates Institute for Agriculture and Biotechnology of Drylands, Jacob Blaustein Institutes for \\ Desert Research, Sede Boqer Campus, Ben-Gurion University of the Negev, Midreshet Ben-Gurion, \\ Beersheba 8499000, Israel; sappl@bgu.ac.il \\ * Correspondence: Johannes.pasch@uni-rostock.de; Tel.: +49-381-4980-3734 \\ + These authors contributed equally to this work.
}

check for updates

Citation: Pasch, J.; Appelbaum, S.; Palm, H.W.; Knaus, U. Growth of Basil (Ocimum basilicum) in Aeroponics, DRF, and Raft Systems with Effluents of African Catfish (Clarias gariepinus) in Decoupled Aquaponics (s.s.). AgriEngineering 2021, 3, 559-574. https://doi.org/ 10.3390/agriengineering3030036

Academic Editor: Eugenio Cavallo

Received: 5 June 2021

Accepted: 12 July 2021

Published: 15 July 2021

Publisher's Note: MDPI stays neutral with regard to jurisdictional claims in published maps and institutional affiliations.

Copyright: (c) 2021 by the authors. Licensee MDPI, Basel, Switzerland. This article is an open access article distributed under the terms and conditions of the Creative Commons Attribution (CC BY) license (https:/ / creativecommons.org/licenses/by/ $4.0 /)$.

\begin{abstract}
Basil (Ocimum basilicum) was cultivated in three hydroponic subsystems (i) a modified commercial aeroponics, (ii) a dynamic root floating (DRF) system, and (iii) a floating raft system in a decoupled aquaponic system in Northern Germany, Mecklenburg-Western Pomerania. For plant nutrition, aquaculture process water from intensive rearing of African catfish (Clarias gariepinus) was used without fertilizer. After 39 days, 16 plant growth parameters were compared, with aeroponics performing significantly better in 11 parameters compared with the DRF, and better compared with the raft in 13 parameters. The economically important leaf wet and dry weight was over $40 \%$ higher in aeroponics $(28.53 \pm 8.74 \mathrm{~g} ; 4.26 \pm 1.23 \mathrm{~g})$, but similar in the DRF $(20.19 \pm 6.57 \mathrm{~g} ; 2.83 \pm 0.90 \mathrm{~g})$ and raft (20.35 $\pm 7.14 \mathrm{~g} ; 2.84 \pm 1.04 \mathrm{~g})$. The roots in the DRF grew shorter and thicker; however, this resulted in a higher root dry weight in aeroponics $(1.08 \pm 0.38 \mathrm{~g})$ compared with the DRF $(0.82 \pm 0.36 \mathrm{~g})$ and raft $(0.67 \pm 0.27 \mathrm{~g})$. With optimal fertilizer and system improvement, aquaponic aeroponics (s.s.) could become a productive and sustainable large-scale food production system in the future. Due to its simple construction, the raft is ideal for domestic or semi-commercial use and can be used in areas where water is neither scarce nor expensive. The DRF system is particularly suitable for basil cultivation under hot tropical conditions.
\end{abstract}

Keywords: basil; African catfish; dynamic root floating technique (DRF); floating raft; deep flow technique (DFT); aeroponics; aquaponics; hydroponics

\section{Introduction}

Aquaponics, the sustainable and resource-friendly cultivation of aquatic organisms and plants in recirculating systems, has become an increasingly popular field of science [1]. Different hydroponic subsystems have been tested with various fish and plant combinations in recent years. Nevertheless, there is still the need for research in testing the various hydroponic subsystems for the highest possible yield. Best suited to evaluate the performance of different hydroponic subsystems in aquaponics are plants and fishes that have already achieved good results.

Herbs such as sweet basil (Ocimum basilicum L.) are particularly suitable for aquaponics because they grow rapidly [2,3], their essential oil is used in medical treatments [4], and they are among the economically most important herbs worldwide [5,6]. In various experiments, excellent yields were achieved under both hydroponic and aquaponic conditions [7-9]. It has also been shown that high basil stocking densities lead to a beneficial relationship between the African catfish C. gariepinus and the plants. Fish injuries were reduced and behavioral patterns were positively influenced [10]. 
African catfish (Clarias gariepinus Burchell, 1822) is an important aquaculture species with a worldwide production of $200 \mathrm{k}$ tons [11]. It is also applied for aquaponic research due to its uncomplicated breeding and excellent feed conversion ratio (FCR) $[7,12,13]$. In combination with basil, the African catfish has shown good growth performance [14,15] and was able to produce juvenile fish (initial weight of $<10 \mathrm{~g}$ ) with an FCR of 0.61 [13], small fish $(40 \mathrm{~g})$ at 0.74 , medium fish $(350 \mathrm{~g})$ at 0.84 , and larger fish $(>1 \mathrm{~kg})$ at 0.91 [7]. The aquaponic fish-plant combination C. gariepinus and O. basilicum is suitable to compare the basil growth performance in different hydroponic subsystems under coupled or decoupled aquaponics conditions. In a decoupled aquaponics system, the aquaculture and hydroponic units are separated from each other, and there is, in contrast to coupled systems, no backflow of the process water from the plants to the fish.

One of the most popular aquaponic cultivation systems is the floating raft system (raft or the deep flow technique (DFT)). In a comparison of the raft with media bed systems under a combination of sweet basil and channel catfish, the raft system performed best in aquaponic yield, fresh leaf mass, and total vegetative (non-root) biomass [8]. In a hydroponic comparison, different basil cultivars were able to produce $2.6 \mathrm{~g}$ more fresh mass in a raft system after 3 weeks compared with the nutrient film technique (NFT) [16].

One of the least-known hydroponic systems is the DRF (dynamic root floating technique), which has only been used four times in aquaponic research so far [17-20]. It was originally developed for the year-round production of vegetables in Taiwan [21] but can also be used as a technique to reduce electric power consumption [20]. By creating an air space between shoot and nutrient solution, root activity can be maintained at high water temperatures $[17,21]$. In a decoupled experiment with African catfish and Moroccan mint (Mentha spicata) during spring in Northern Germany, the DRF produced less leaf biomass and shorter plants compared with the raft [18]. In a subsequent summer experiment (cet. par.) at an average water temperature of $28.0 \pm 2.4^{\circ} \mathrm{C}$, the DRF system performed better than raft in 8 of 16 investigated plant growth parameters [17].

Another new hydroponic cultivation system is aeroponics, and the literature about this subsystem in aquaponics is scarce. It was originally developed in the 1920s by botanists who used earlier aeroponic techniques as a research tool for root physiology [22]. The basic principle of modern aeroponics is to grow the plants in a closed or semi-closed environment by spraying the roots continuously or intermittently with a nutrient-rich fertilizer solution [22-24]. The system design can vary greatly, whereby the correct combination of pressure, nozzles, and thus droplet size, misting intervals, and root zone volume have a significant influence on the growth performance of the plants $[25,26]$. According to NASA, aeroponic systems can reduce water usage by $98 \%$, fertilizer usage by $60 \%$, and pesticide usage by $100 \%$, while increasing crop yields by $45-75 \%$ [27]. In addition, aeroponics allows better control over plant growth parameters as well as pests or diseases. Thus, through the elimination of growth media substrates, the resource input consequently decreases, also making aeroponics attractive as a crop production option for (interplanetary) space flights [28].

Aeroponics is especially useful for crops whose roots are harvested as the end product, such as potatoes, yams, or ginger, but is also increasingly used for the cultivation of numerous vegetable crops, such as lettuce, tomatoes, and herbs [26]. Aeroponics has been successfully applied in the production of potato minitubers [24] since the harvest is convenient and clean and allows better size control [29]. There is so far little research on aeroponic cultivation of crops where above-ground parts are to be used for harvesting. In an experiment with valerian (Valeriana officinalis), the aeroponics system formed less fresh weight of both leaves and roots and less leaf area than the floating media system, along with the concentration of essential oils [30]. In contrast, in an experiment with tomatoes, the aeroponics system was able to produce significantly higher yields $\left(40 \mathrm{~kg} / \mathrm{m}^{2}\right)$ than a stone wool system $\left(32 \mathrm{~kg} / \mathrm{m}^{2}\right)$ and soil cultivation $\left(36 \mathrm{~kg} / \mathrm{m}^{2}\right)$ [31]. Another study concluded that basil plants grown aeroponically were of superior nutritional quality [25]. 
This study examined the growth of sweet basil (O. basilicum) in three different hydroponic subsystems under decoupled aquaponic conditions with the intensive culture of African catfish (C. gariepinus). The plants grew in (i) a modified commercial aeroponics (AERO), (ii) a dynamic root floating (DRF) system, and (iii) a floating raft (raft) system without the addition of fertilizers under controlled greenhouse conditions. The plant and fish growth performance, together with the physicochemical water parameters, are analyzed and discussed.

\section{Materials and Methods}

The experiment was carried out in a $100 \mathrm{~m}^{2}$ greenhouse cabin and in an intensive aquaculture unit (IAU) in the FishGlassHouse (FGH) (latitude: 54.075714, longitude: 12.096591) of the University of Rostock, Rostock, Germany. The IAU consisted of nine fish tanks $\left(1 \mathrm{~m}^{3}\right)$ with a stocking density of 120 fish $/ \operatorname{tank}\left(\max 200 \mathrm{~kg} / \mathrm{m}^{3}\right)$, a sedimentation tank $\left(1.7 \mathrm{~m}^{3}\right)$, a pump sump $\left(6 \mathrm{~m}^{3}\right)$, and a trickling filter $\left(17 \mathrm{~m}^{3}\right)$. The effluent from the production of $C$. gariepinus was pumped twice a week through transfer tanks into the greenhouse cabin. A drum filter (Wasserfilteranlage ITF 30, 25-30 m³ $/ \mathrm{h}$, Fackler Gewächshaustechnik, Munningen, Germany) was interposed between the transfer tank and the planting cabin for solids removal. The aquaponic principle was decoupled, and no additional fertilizer was used.

\subsection{Hydroponics Unit}

The three techniques-aeroponics (AERO), the dynamic root floating (DRF), and floating raft (raft) - were tested in triplicates and a randomized block design (Figure 1). The cabin contained a pump sump and nine hydroponic channels, each with seven basil plants at a distance of $20 \mathrm{~cm}$. A total of $2450 \mathrm{~L}$ was pumped from the IAU into the system at the start of the experiment. On Tuesdays and Fridays, the water was drained from the pump sump, and $540 \mathrm{~L}$ of process water was refilled. A $780-\mathrm{W}$ pump distributed the nutrient solution to the DRF and raft channels, and another 780-W pump supplied the AERO channels; here, an additional filter (Universalfilter II, BWT, Schriesheim, Germany) was interposed without a filter sleeve to prevent clogging of the AERO nozzles. Using flow regulators, the inflow was set to $4 \mathrm{~L} / \mathrm{min} /$ channel.

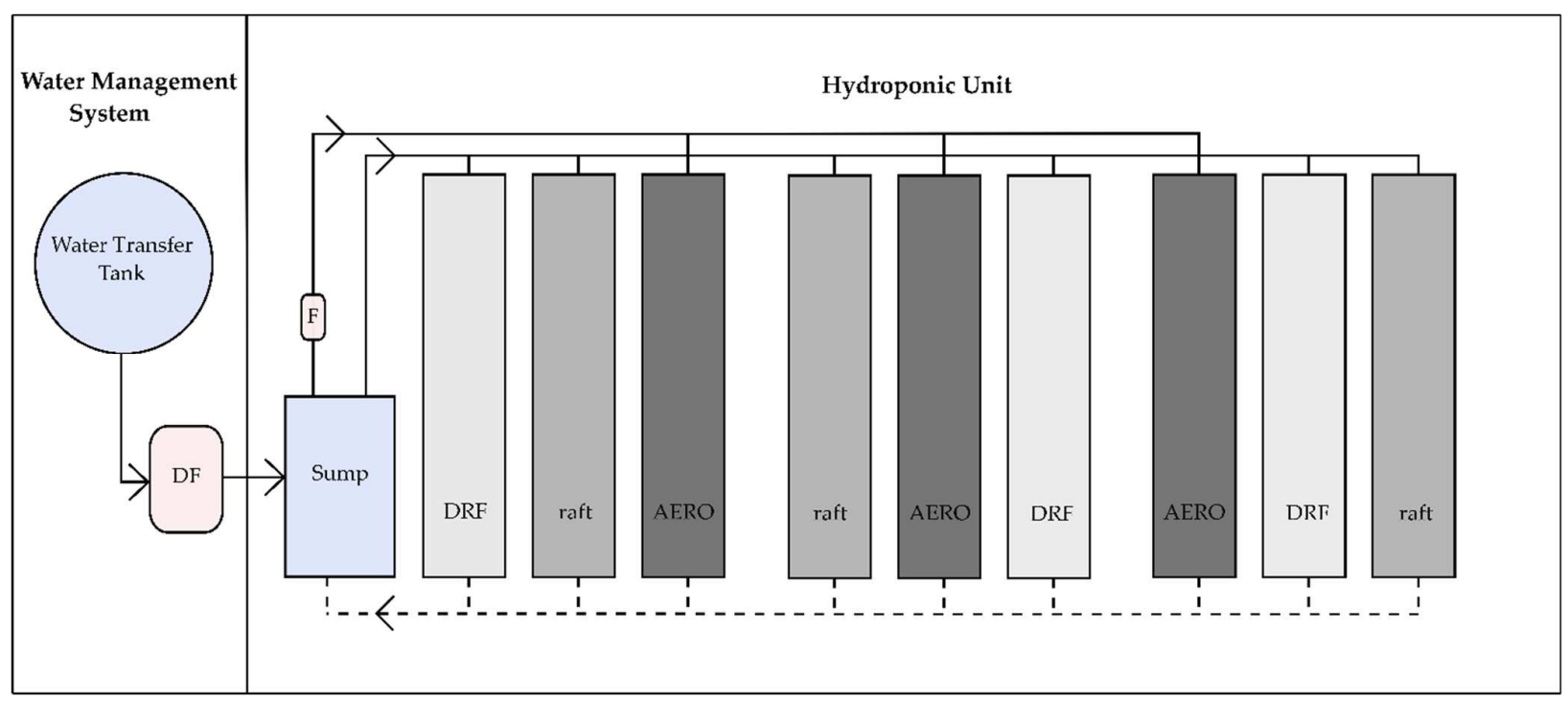

Figure 1. Schematic illustration of the decoupled experimental hydroponics cycle with DRF, raft, and AERO hydroponic subsystems in cabin 1_05 of the FischGlasHaus. DF: drum filter; F: filter. Aquaculture effluent water from C. gariepinus production was pumped to the water transfer tank. 


\subsubsection{Dynamic Root Floating Technique (DRF)}

Glass fiber channels made of reinforced plastic with the dimensions $280 \mathrm{~cm} \times 40 \mathrm{~cm}$ $\times 45 \mathrm{~cm}$, filled with $317 \mathrm{~L}$ of water, were used. The seedlings were placed in grid pots with a diameter of $8 \mathrm{~cm}$, which were placed in the holes of 40-mm-thick polystyrene rafts. Over a period of 14 days, a membrane pump (Aqua Medic Mistral 4000, MEDIC GmbH, Bissendorf, Germany) pumped approximately $4000 \mathrm{~L} / \mathrm{h}$ of air through $4 / 6 \mathrm{~mm}$ air hoses with two air stones per tank into the process water. Afterward, the grid pots were closed by using transparent film, and the water level was continuously lowered by $1 \mathrm{~cm}$ daily with the help of a variable drain regulator until a total air space of $5 \mathrm{~cm}$ was reached (Figure 2).

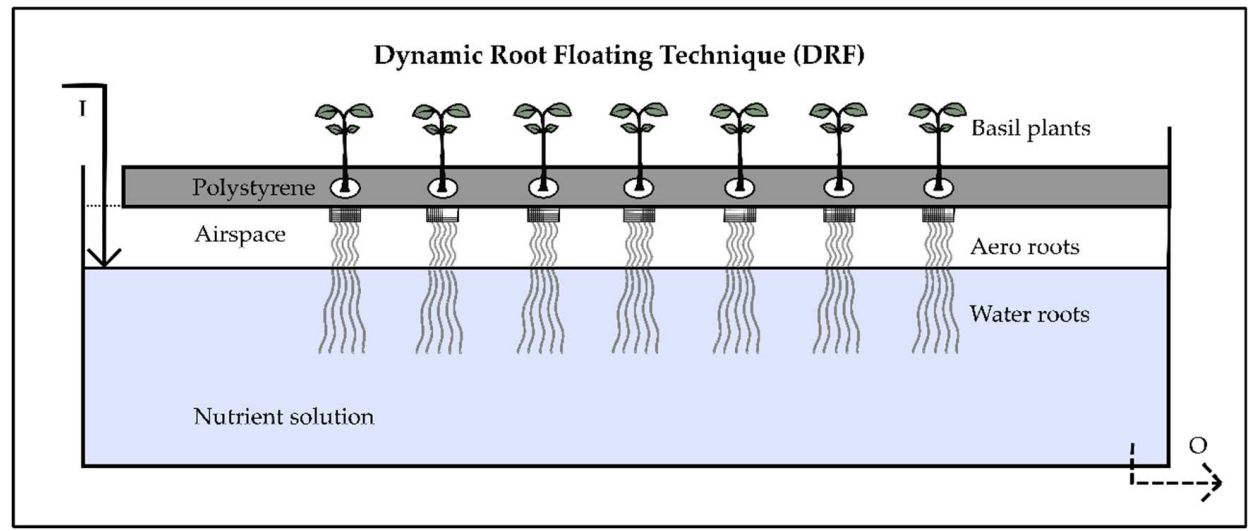

Figure 2. Schematic illustration of the dynamic root floating (DRF) system with air space of $5 \mathrm{~cm}$. $\mathrm{I}=$ inflow, $\mathrm{O}=$ outflow.

\subsubsection{Floating Raft Culture (Raft)}

The raft system used glass fiber channels made of reinforced plastic $(280 \mathrm{~cm} \times 40 \mathrm{~cm}$ $\times 45 \mathrm{~cm}$ ). Each channel was filled with $317 \mathrm{~L}$ of water. The $40-\mathrm{mm}$-thick polystyrene rafts had holes for grid pots with a diameter of $8 \mathrm{~cm}$ in which the seedlings were placed. A membrane pump (Aqua Medic Mistral 4000, MEDIC GmbH, Bissendorf, Germany) transported about $4000 \mathrm{~L} / \mathrm{h}$ of air through $4 / 6 \mathrm{~mm}$ air hoses, with two air stones per channel, into the process water during the entire experiment.

\subsubsection{Aeroponics (AERO)}

For aeroponics, modified square channels from the commercial GHE AeroFlo40 system (GHE, Fleurance, France) were used. The channels were made of polyvinyl chloride (PVC) and had a length of $200 \mathrm{~cm}$, a height and width of $12 \mathrm{~cm}$, and a slope of $2.12 \%$. Each pipe had seven holes at 20-cm intervals for the basil seedlings in the 8-cm diameter grid pots (Figure 3). At the edge of the channels, eight $180^{\circ}$ spray nozzles (micro-drip-system, Gardena, Ulm, Germany) were installed around the roots, which sprayed them constantly with the African catfish process water from the sump. The grid pots were closed using transparent film.

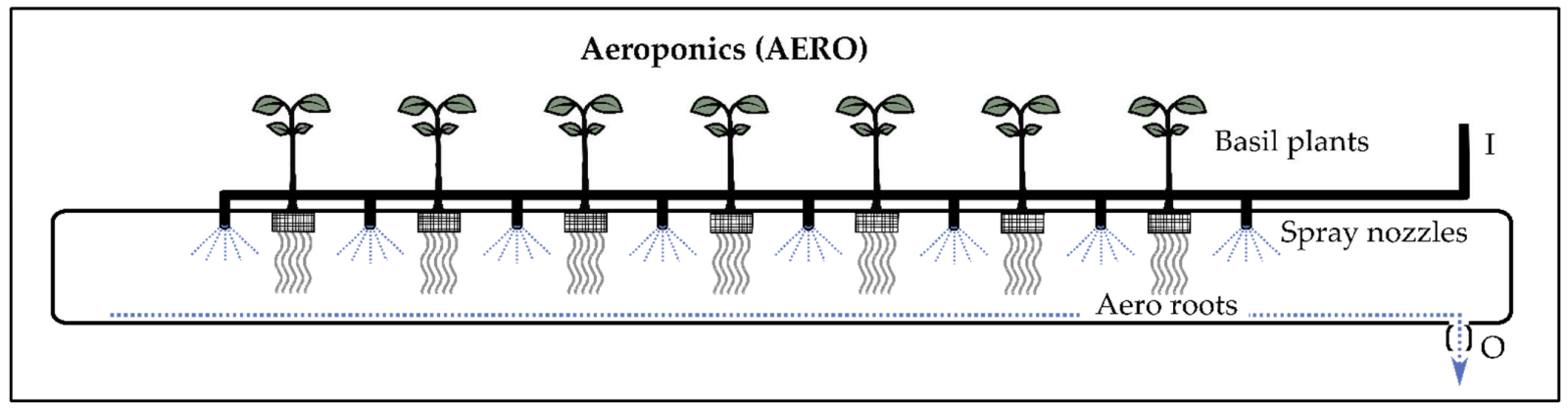

Figure 3. Schematic illustration of the aeroponics system (AERO). I = inflow, $\mathrm{O}=$ outflow. 


\subsubsection{Fish Production and Feeding}

African catfish (Clarias gariepinus) was cultivated in the intensive aquaculture unit (IAU) of the FishGlassHouse. In nine tanks, three weight-size classes were cultured in three tanks, each with 120 fish/tank. Size class 1 was the largest fish with an average weight of $1266.68 \mathrm{~g}$ ( \pm 86.46$)$. Size class 2 was $838.46 \mathrm{~g}( \pm 17.66)$, and size class 3 was $42.78 \mathrm{~g}$ $( \pm 0.69)$. A commercial African catfish feed, SPECIAL PRO EF $4.5 \mathrm{~mm}$ (Alltech Coppens BV, Leende, The Netherlands), was used, with $42 \%$ crude protein, $13 \%$ crude fat, $1.5 \%$ fiber, $7.6 \%$ ash, $1.02 \%$ phosphorus, $1.9 \%$ calcium, and $0.3 \%$ sodium. The fish feeding was conducted according to the protocol of PAL Anlagenbau GmbH (Abtshagen, Germany) and was adjusted to $50 \%$ of a commercial African catfish farm.

\subsection{Plant Cultivation}

The watered seeds of Ocimum basilicum were sown in seed coats with a substrate of peat, perlite, and coconut fibers (Eazy Plug, Goirle, The Netherlands) on 2 March 2020 and placed in seedling trays. On 22 March 2020, 63 randomly selected plants with an average height of $6.56 \mathrm{~cm}$ and 3.5 leaves were transplanted into the grid pots of the hydroponic subsystems. Supplemental lighting from high-pressure sodium lamps (400-watt MASTER SON-T, Philipps, Amsterdam, The Netherlands) was automatically switched on between 06:00 a.m. and 22:00 p.m. when greenhouse light intensities fell below $10.00 \mathrm{klx}$. The plants were illuminated with $14.50 \mathrm{klx}$ and supplemented with a photosynthetic photon flux density (PPFD) of $270 \mu \mathrm{mol} / \mathrm{m}^{2} \mathrm{~s}$. No fertilizer was added.

The following parameters were examined 39 days after the plants were transplanted into the hydroponic subsystems (30 April 2020): total wet weight (g), total height ( $\mathrm{cm}$ ), leaf mass wet weight (g), number of leaves no longer than $3 \mathrm{~mm}$ (No.), shoot axis wet weight (g), shoot axis height $(\mathrm{cm})$, root wet weight $(\mathrm{g})$ and root length $(\mathrm{cm})$. The weights $(\mathrm{g})$, lengths $(\mathrm{cm})$, widths $(\mathrm{cm})$, chlorophyll content, and colorimeter index of the leaves were determined using the mean values of the two leaves of the third upper shoot node. Chlorophyll content was measured using a SPAD (Soil Plant Analysis Development) meter (SPAD-502PLUS, Konica Minolta, Inc., Marunouchi, Japan). The colorimeter index was determined using a colorimeter (PCE-CSM 2, PCE Deutschland GmbH, Meschede, Germany). After data acquisition, the samples were dried for $72 \mathrm{~h}$ at $60{ }^{\circ} \mathrm{C}$ and then for $2 \mathrm{~h}$ at $120^{\circ} \mathrm{C}$ in a drying oven (UF750 plus, Memmert GmbH \& Co. KG, Schwabach, Germany). Subsequently, the total dry weight $(\mathrm{g})$ and the dry mass of leaves $(\mathrm{g})$, shoots $(\mathrm{g})$, and roots $(\mathrm{g})$ of all plants were determined. Once a week, the number of leaves (No.) and shoot height $(\mathrm{cm})$ were measured.

\subsection{Physicochemical Parameters}

Physical water parameters were taken from the pump sump of the hydroponics unit on the weekdays by using a HQ40d multimeter (Hach Lange GmbH, Düsseldorf, Germany). Oxygen saturation $(\%)$, oxygen concentration $(\mathrm{mg} / \mathrm{L})$, water temperature $\left({ }^{\circ} \mathrm{C}\right), \mathrm{pH}$ value, conductivity $(\mu \mathrm{S} / \mathrm{cm})$, redox potential $(\mathrm{mV})$, and salinity $(\%)$ were measured. Water samples from the pump sump were taken Tuesdays and Fridays before the water exchange and analyzed with the Gallery ${ }^{\mathrm{TM}}$ Analyzer (Thermo Fisher Scientific, Waltham, MA, USA) to determine the concentrations of the following chemical parameters: ammonium $\left(\mathrm{NH}_{4}{ }^{+}\right)$, nitrite $\left(\mathrm{NO}_{2}{ }^{-}\right)$, nitrate $\left(\mathrm{NO}_{3}{ }^{-}\right)$, phosphate $\left(\mathrm{PO}_{4}{ }^{3-}\right)$, potassium $\left(\mathrm{K}^{+}\right)$, magnesium $\left(\mathrm{Mg}^{2+}\right)$, calcium $\left(\mathrm{Ca}^{2+}\right)$, iron $\left(\mathrm{Fe}^{2+}\right)$, and sulfate $\left(\mathrm{SO}_{4}{ }^{3-}\right)$. TON (total oxidized nitrogen) as $\mathrm{N}$ and nitrate (calculation: TON-nitrite) was analyzed by using the colorimetric hydrazine method (template: D08896_01 ${ }^{\odot} 2015$ Thermo Fisher Scientific Inc., Waltham, MA USA). Nitrate was reduced to nitrite using hydrazine under alkaline conditions. The total nitrite ions were converted to a pink azo dye by using $N$-1-naphthylethylenediamine dihydrochloride and sulfanilamide under acidic conditions. The absorbance was determined at $540 \mathrm{~nm}$ and related to the TON concentration by means of a calibration curve. 


\subsection{Mathematical and Statistical Analysis}

The fish data were collected on 13 March 2020 and 49 days later on 1 May 2020. The total weight and the number of fish per tank, as well as three animals per tank, were measured individually. Feed conversion ratio (FCR, Equation (1)), the specific growth rate (SGR, 2), the biomass increase, the condition factor $(C, 3)$, the percentage growth $(G, 4)$, and the total color difference $\left(\Delta E_{x, y}, 5\right)$ between plants of the different systems by using the $L^{*} a^{*} b$ coordinates were calculated as follows:

$$
\begin{gathered}
F C R=\text { fish feed quantity }(\mathrm{kg}) / \text { weight gain }(\mathrm{kg}) \\
S G R(\% / \text { day })=\left(\ln W_{t}-\ln W_{0}\right) / t \times 100
\end{gathered}
$$

where $W_{t}=$ final biomass $(\mathrm{kg}) ; W_{0}=$ initial biomass $(\mathrm{kg}) ; t=$ time in days.

$$
C=(W \times 100) / L^{3}
$$

where $W=$ fish weight $(\mathrm{g}) ; L=$ fish length $(\mathrm{cm})$.

$$
G=\text { Growth fish weight class } \times(\%)=\left(F_{x}-I_{x}\right) \times 100 / I_{x}
$$

where $F_{x}=$ final weight, fish weight class $\mathrm{x} ; I_{x}=$ initial weight, fish weight class $\mathrm{x}$.

$$
\Delta E_{x, y}=\left(\left(L_{x}-L_{y}\right)^{2}+\left(a_{x}-a_{y}\right)^{2}+\left(b_{x}-b_{y}\right)^{2}\right)^{1 / 2}
$$

where $L=$ difference in lightness and darkness (higher value $=$ light); $a=$ difference in red and green (higher value $=$ red); $b=$ difference in yellow and blue (higher value $=$ yellow); $x=$ color coordinate of system $\mathrm{x} ; y=$ color coordinate of system $\mathrm{y}$.

Statistical analysis was performed for all plant growth and physico-chemical parameters and the following fish growth parameters: initial and final fish length $(\mathrm{cm})$, fish mass (g), tank mass (kg), feed conversion ratio (FCR), specific growth rate (SGR), condition factor (C), and growth per tank ( $\mathrm{kg}$ and \%).

Microsoft Excel ${ }^{\circledR} 2010$ [32] and the SPSS ${ }^{\circledR} 23$ software package [33] were used for data processing and analysis. Normally distributed data were processed with One-Way Analysis of Variance (ANOVA), and at variance homogeneity, multiple mean comparisons were performed post hoc using Tukey-HSD (Honestly Significant Difference) test. For variance-inhomogeneous data, the Dunnett-T3 test was used. For non-normal distribution, the nonparametric Kruskal-Wallis test was applied. The significance level remained at $p<0.05$.

\section{Results}

\subsection{Fish Growth}

The initial mean lengths were $56.93 \mathrm{~cm}$ (fish weight class 1, large fish), $48.10 \mathrm{~cm}$ (class 2, medium), and $17.33 \mathrm{~cm}$ (class 3, small), and the final mean lengths were $57.43 \mathrm{~cm}, 53.26 \mathrm{~cm}$, and $27.81 \mathrm{~cm}$ (Table 1), respectively. The initial fish weights of the three fish weight classes were $1266.68 \mathrm{~g}$ (large, total tank biomass of $148.00 \mathrm{~kg}$ ), $838.46 \mathrm{~g}$ (medium, $100.71 \mathrm{~kg}$ ), and $42.78 \mathrm{~g}$ (small, $5.13 \mathrm{~kg}$ ), respectively. The final fish weights were $1571.48 \mathrm{~g}(182.74 \mathrm{~kg})$, $1147.13 \mathrm{~g}(133.44 \mathrm{~kg})$, and $133.24 \mathrm{~g}(15.63 \mathrm{~kg})$, respectively.

The growth per tank for fish weight class 1 was $34.74 \mathrm{~kg}$ or $23.50 \%$. Class 2 had $32.73 \mathrm{~kg}, 32.73 \%$, and class 3 had $10.50 \mathrm{~kg}$ with an increase of $204.56 \%$. The FCR was highest for large fish (1.27), followed by medium fish (1.17) and small fish (0.84). For SGR, fish weight class 1 had $0.45 \%$ /day, class $20.60 \%$ /day, and class $32.37 \%$ /day. The condition factor was highest for the fish weight class 1 with 0.83 , followed by class $3(0.81)$ and class 2 (0.76). 
Table 1. Growth parameters (means \pm SD) of African catfish of different weight classes (class $1=$ large fish, class 2 = medium fish, class 3 = small fish) held in the intensive aquaculture unit (IAU) (49 days); different letters represent significant differences between the groups $(p<0.05)$.

\begin{tabular}{|c|c|c|c|c|c|c|}
\hline Parameters & Weight Class 1 & Weight Class 2 & Weight Class 3 & $\mathrm{P}-\mathrm{I}^{1}$ & P-II ${ }^{1}$ & P-III ${ }^{1}$ \\
\hline Fish initial length (cm) & $56.93 \pm 1.38^{a, 2}$ & $48.10 \pm 1.81^{b}$ & $17.33 \pm 1.58^{\mathrm{c}}$ & 0.001 & 0.001 & 0.001 \\
\hline Fish final length $(\mathrm{cm})$ & $57.43 \pm 3.01^{\mathrm{a}}$ & $53.26 \pm 1.98^{b}$ & $27.81 \pm 1.28^{c}$ & 0.001 & 0.001 & 0.001 \\
\hline Fish initial weight $(\mathrm{g})$ & $1266.68 \pm 86.46^{\mathrm{a}}$ & $838.46 \pm 17.66^{b}$ & $42.78 \pm 0.69^{c}$ & 0.023 & 0.003 & 0.001 \\
\hline Fish final weight $(\mathrm{g})$ & $1571.48 \pm 44.06^{\mathrm{a}}$ & $1147.13 \pm 11.52^{b}$ & $133.24 \pm 2.20^{c}$ & 0.005 & 0.001 & 0.001 \\
\hline Tank initial mass (kg) & $148.00 \pm 3.69^{a}$ & $100.71 \pm 2.29 b$ & $5.13 \pm 0.08^{c}$ & 0.001 & 0.001 & 0.001 \\
\hline Tank final mass (kg) & $182.74 \pm 1.71^{\mathrm{a}}$ & $133.44 \pm 3.21^{b}$ & $15.63 \pm 0.30^{c}$ & 0.001 & 0.001 & 0.001 \\
\hline Growth per tank (kg) & $34.74 \pm 2.00^{\mathrm{a}}$ & $32.73 \pm 1.07^{\mathrm{a}}$ & $10.50 \pm 0.25^{b}$ & 0.226 & 0.001 & 0.001 \\
\hline Growth per tank $(\%)$ & $23.50 \pm 1.93^{c}$ & $32.73 \pm 0.65^{b}$ & $204.56 \pm 4.29^{\mathrm{a}}$ & 0.020 & 0.001 & 0.001 \\
\hline Feed conversion ratio (FCR $)^{3}$ & $1.27 \pm 0.09^{\mathrm{a}}$ & $1.17 \pm 0.03^{\mathrm{a}}$ & $0.84 \pm 0.02^{\mathrm{b}}$ & 0.132 & 0.001 & 0.001 \\
\hline Specific growth rate (\%/day) ${ }^{3}$ & $0.45 \pm 0.03^{c}$ & $0.60 \pm 0.01^{b}$ & $2.37 \pm 0.03^{\mathrm{a}}$ & 0.001 & 0.001 & 0.001 \\
\hline Condition factor $(\mathrm{C})$ & $0.83 \pm 0.10^{\mathrm{a}}$ & $0.76 \pm 0.07^{\mathrm{a}}$ & $0.81 \pm 0.15^{\mathrm{a}}$ & 0.447 & 0.931 & 0.665 \\
\hline
\end{tabular}

${ }^{1}$ Significances, with P-I = between fish weight class 1 and 2, P-II = between weight class 1 and 3, P-III = between weight class 2 and 3. 2 Means in each row followed by the same superscript letters indicate no significant differences among the fish growth parameters. Means with different letters are statistically different, in that the mean with the lower alphabetical order letter (e.g., a >c) has a mean statistically greater than the mean it is compared to. ${ }^{3} \mathrm{FCR}$ and specific growth rate based on tank biomasses: $n=3$.

\subsection{Plant Growth}

The growth of $O$. basilicum showed plant-typical exponential growth. The total wet weight was similar in the DRF (46.80 g) and raft $(44.28 \mathrm{~g})$ and significantly higher in AERO $(62.29 \mathrm{~g})$ (Table 2, Figure 4). The total height was just above $70 \mathrm{~cm}$ in all plants. Leaf mass wet weight was similar in the DRF (20.19 g) and raft (20.35 g), while AERO had almost $40 \%$ more leaf biomass $(28.53 \mathrm{~g})$. There was no significant difference in the number of leaves, although AERO (119.45 leaves) had more leaves than the DRF (102.25 leaves) and raft (101.33 leaves) (Figure 5).

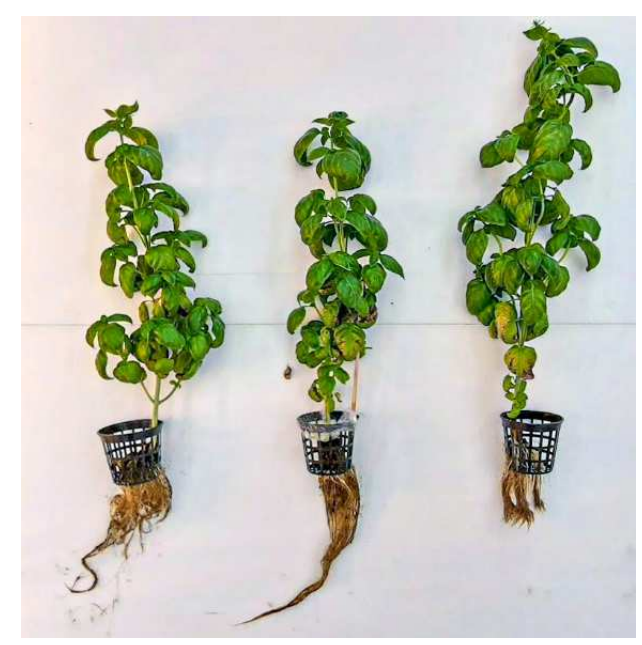

Figure 4. Average basil plants at the end of the experiment with visibly longer and finer roots and similar shoot growth performance in DRF (left) and raft (middle). Short but compact root growth and a better shoot growth performance in AERO (right). 
Table 2. Growth parameters (means \pm SD) wet and dry mass of Ocimum basilicum in the three hydroponic subsystems (dynamic root floating technique: DRF, floating raft culture: raft, aeroponics: AERO) at the end of the experiment (39 days); different letters represent significant differences between the groups $(p<0.05, n=21)$. The third part of the table shows total and leaf mass of Ocimum basilicum (wet and dry) produced by one system over the experimental period without statistical comparison. The last two parts show the color differences of the plants from the colorimeter indexes $L^{*} a^{*} b$ and the total color differences between the systems.

\begin{tabular}{|c|c|c|c|c|c|c|}
\hline Growth Parameters & DRF & Raft & AERO & P-I ${ }^{1}$ & P-II ${ }^{1}$ & P-III ${ }^{1}$ \\
\hline Total wet weight (g) & $46.80 \pm 13.78^{b, 2}$ & $44.28 \pm 13.19^{b}$ & $62.20 \pm 17.01^{a}$ & 0.694 & 0.002 & 0.007 \\
\hline Total height $(\mathrm{cm})$ & $70.38 \pm 10.40^{\mathrm{a}}$ & $70.62 \pm 10.46^{\mathrm{a}}$ & $70.96 \pm 6.81^{\mathrm{a}}$ & 0.996 & 0.979 & 0.993 \\
\hline Leaf mass wet weight $(\mathrm{g})$ & $20.19 \pm 6.57^{b}$ & $20.35 \pm 7.14^{b}$ & $28.53 \pm 8.74^{\mathrm{a}}$ & 0.997 & 0.003 & 0.003 \\
\hline Leaves (No.) & $102.25 \pm 23.67^{\mathrm{a}}$ & $101.33 \pm 29.42^{\mathrm{a}}$ & $119.45 \pm 29.55^{a}$ & 0.994 & 0.131 & 0.100 \\
\hline Shoot axis wet weight $(\mathrm{g})$ & $12.48 \pm 4.20^{\mathrm{b}}$ & $12.22 \pm 3.92^{b}$ & $17.93 \pm 5.51^{\mathrm{a}}$ & 0.996 & 0.004 & 0.002 \\
\hline Shoot axis height $(\mathrm{cm})$ & $40.81 \pm 5.48^{b}$ & $42.22 \pm 7.29^{b}$ & $52.04 \pm 6.83^{\mathrm{a}}$ & 0.772 & 0.001 & 0.001 \\
\hline Root wet weight (g) & $14.13 \pm 3.74^{\mathrm{a}}$ & $11.71 \pm 2.90^{b}$ & $15.72 \pm 4.24^{\mathrm{a}}$ & 0.031 & 0.364 & 0.002 \\
\hline Root length $(\mathrm{cm})$ & $29.58 \pm 6.44^{\mathrm{a}}$ & $28.41 \pm 6.11^{\mathrm{a}}$ & $18.80 \pm 5.00^{b}$ & 0.800 & 0.001 & 0.001 \\
\hline Leaf wet weight $(\mathrm{mg})^{3}$ & $696.83 \pm 143.47^{b}$ & $704.62 \pm 138.11^{b}$ & $789.33 \pm 159.41^{a}$ & 0.927 & 0.031 & 0.036 \\
\hline Leaf length $(\mathrm{cm})^{3}$ & $7.31 \pm 0.69^{b}$ & $7.35 \pm 0.72^{b}$ & $7.89 \pm 0.74^{\mathrm{a}}$ & 0.820 & 0.005 & 0.010 \\
\hline Leaf width $(\mathrm{cm})^{3}$ & $4.81 \pm 0.59^{b}$ & $4.79 \pm 0.52^{b}$ & $5.14 \pm 0.52^{\mathrm{a}}$ & 0.928 & 0.017 & 0.020 \\
\hline Leaf SPAD-Value ${ }^{3}$ & $37.00 \pm 2.86^{a}$ & $33.58 \pm 3.15^{b}$ & $36.58 \pm 4.08^{a}$ & 0.006 & 0.921 & 0.019 \\
\hline Dry Weight Parameters & DRF & Raft & AERO & P-I ${ }^{1}$ & P-II 1 & P-III ${ }^{1}$ \\
\hline Total dry weight (g) & $5.20 \pm 1.63^{b}$ & $4.96 \pm 1.78^{b}$ & $7.60 \pm 2.21^{\mathrm{a}}$ & 0.913 & 0.001 & 0.001 \\
\hline Leaf mass dry weight (g) & $2.83 \pm 0.90^{b}$ & $2.84 \pm 1.04^{b}$ & $4.26 \pm 1.23^{\mathrm{a}}$ & 0.999 & 0.001 & 0.001 \\
\hline Shoot axis dry weight (g) & $1.55 \pm 0.50^{b}$ & $1.45 \pm 0.55^{b}$ & $2.26 \pm 0.75^{\mathrm{a}}$ & 0.848 & 0.001 & 0.001 \\
\hline Root dry weight $(\mathrm{g})$ & $0.82 \pm 0.36^{\mathrm{b}}$ & $0.67 \pm 0.27^{b}$ & $1.08 \pm 0.38^{a}$ & 0.336 & 0.047 & 0.001 \\
\hline Total Weight Parameters ${ }^{4}$ & DRF & Raft & AERO & & & \\
\hline Total wet mass (g) & 935.90 & 929.90 & 1244.00 & - & - & - \\
\hline Wet mass of leaves $(\mathrm{g})$ & 403.80 & 427.40 & 570.60 & - & - & - \\
\hline Total dry mass (g) & 103.95 & 104.10 & 151.99 & - & - & - \\
\hline Dry mass of leaves (g) & 56.55 & 59.65 & 85.24 & - & - & - \\
\hline Colorimeter Index 5 & DRF & Raft & AERO & P-I ${ }^{1}$ & P-II ${ }^{1}$ & P-III ${ }^{1}$ \\
\hline $\mathrm{L}$ & $42.96 \pm 1.89^{a}$ & $44.36 \pm 1.95^{\mathrm{a}}$ & $44.24 \pm 2.33^{a}$ & 0.084 & 0.134 & 0.983 \\
\hline a & $-13.46 \pm 0.82^{a}$ & $-14.11 \pm 0.71^{b}$ & $-13.60 \pm 1.03^{a b}$ & 0.045 & 0.861 & 0.150 \\
\hline $\mathrm{b}$ & $23.89 \pm 2.04^{b}$ & $25.56 \pm 1.59^{a}$ & $25.41 \pm 2.01^{\mathrm{a}}$ & 0.017 & 0.039 & 0.965 \\
\hline \multirow[t]{2}{*}{ Color Difference $\left(\Delta \mathrm{E}_{\mathrm{x}, \mathrm{y}}\right)$} & $\Delta \mathrm{E}_{\mathrm{DRF}, \mathrm{raft}}{ }^{6}$ & $\Delta \mathrm{E}_{\text {raft,AERO }}{ }^{6}$ & $\Delta \mathrm{E}_{\text {DRF,AERO }}{ }^{6}$ & & & \\
\hline & 2.59 & 0.15 & 1.98 & - & - & - \\
\hline
\end{tabular}

\footnotetext{
${ }^{1}$ Significances, with P-I = between DRF and raft, P-II = between DRF and AERO, P-III = between raft and AERO. ${ }^{2}$ Means in each row followed by the same superscript letters indicate no significant differences among the fish growth parameters. Means with different letters are statistically different, in that the mean with the lower alphabetical order letter (e.g., a > c) has a mean statistically greater than the mean it is compared to. ${ }^{3}$ Measured on the leaf of the third upper shoot node. ${ }^{4}$ Total weight parameters calculated as the sum of all individual plants of the respective experimental group. ${ }^{5} \mathrm{~L}=$ difference in lightness and darkness (higher value $=$ light), a difference in red and green (higher value $=$ red), $\mathrm{b}=$ difference in yellow and blue (higher value $=$ yellow). ${ }^{6}$ Total color difference with $\Delta \mathrm{E}_{\mathrm{DRF}}$-raft $=$ between DRF and raft, $\triangle \mathrm{E}_{\text {raft-AERO }}=$ between raft and $\mathrm{AERO}, \triangle \mathrm{E}_{\mathrm{DRF}-\mathrm{AERO}}=$ between DRF and AERO.
}

Shoot axis wet weight and shoot axis height differences were not significant in the DRF $(12.48 \mathrm{~g} ; 40.81 \mathrm{~cm})$ and raft $(12.22 \mathrm{~g} ; 42.22 \mathrm{~cm})$ and were significantly higher in AERO $(17.93 \mathrm{~g} ; 52.04 \mathrm{~cm})$ (Figure 5). The root wet weight showed no statistical difference in the DRF (14.13 g) and AERO (15.72 g), but was significantly higher than in the raft (11.71 g). The root length was again similar in the DRF $(29.58 \mathrm{~cm})$ and raft $(28.41 \mathrm{~cm})$ and significantly longer than AERO $(18.80 \mathrm{~cm}$ ) (Figure 6). An average leaf of the third node (leaf 3) was similar in weight, length, and width for the DRF $(696.83 \mathrm{mg} ; 7.31 \mathrm{~cm} ; 4.81 \mathrm{~cm})$ and raft $(704.62 \mathrm{mg} ; 7.35 \mathrm{~cm} ; 4.79 \mathrm{~cm})$. AERO showed statically heavier and longer leaves in the three parameters than the other two systems $(789.33 \mathrm{mg} ; 7.89 \mathrm{~cm} ; 5.14 \mathrm{~cm})$. The SPAD value in the DRF (37.00) and AERO (36.58) was significantly higher than in the raft (33.58). 

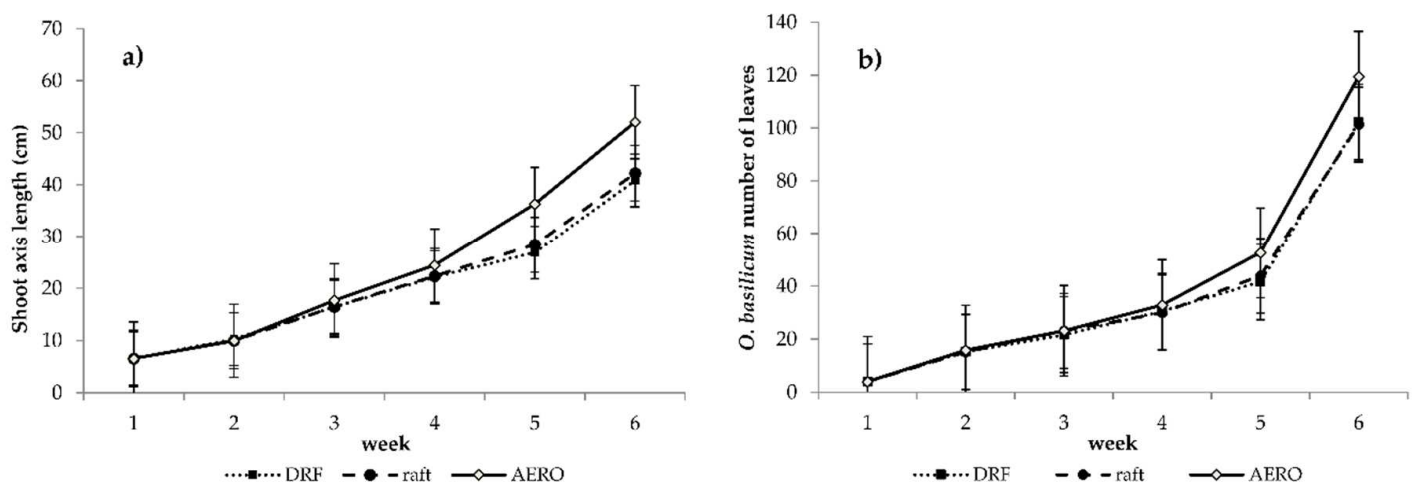

Figure 5. Weekly increase of (a) shoot axis length $(\mathrm{cm})$ and $(\mathbf{b})$ number of leaves of Ocimum basilicum in DRF, raft, and AERO hydroponic subsystems over the trial period (39 days). From the fourth week of the experiment, the AERO system showed increased growth performance.
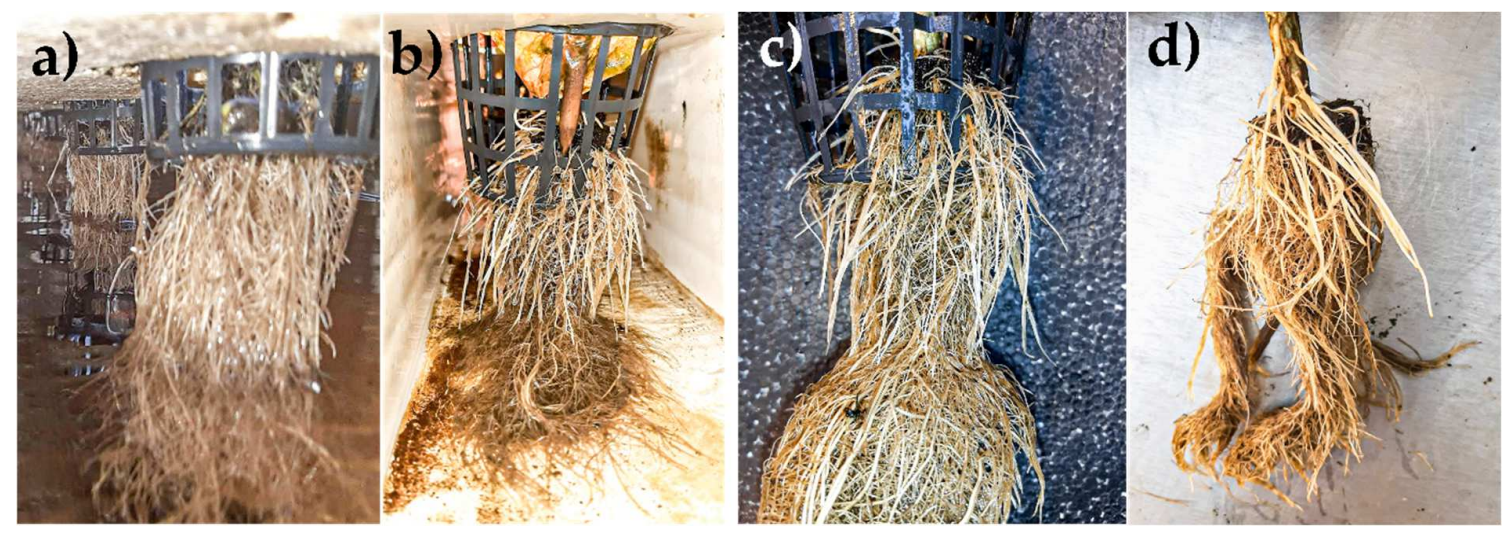

Figure 6. Roots of $O$. basilicum at the end of the experiment: (a) DRF system with roots growing in $5 \mathrm{~cm}$ airspace; (b-d) roots of the aeroponics system are shorter and tangled but with more lateral roots.

Plants in AERO were significantly higher in all four dry weight parameters than in the other two systems. With a total weight of $7.60 \mathrm{~g}$, leaf mass $4.26 \mathrm{~g}$, and shoot axis $2.26 \mathrm{~g}$, AERO was, in each case, more than $45 \%$ above the values for the DRF (total $5.20 \mathrm{~g}$, leaf mass $2.83 \mathrm{~g}$, and shoot axis $1.55 \mathrm{~g})$ and raft $(4.96 \mathrm{~g}, 2.84 \mathrm{~g}, 1.45 \mathrm{~g})$. The root dry weight of AERO with $1.08 \mathrm{~g}$ was more than $61 \%$ heavier than the raft $(0.67 \mathrm{~g})$ and about $32 \%$ heavier than the DRF $(0.82 \mathrm{~g})$. Figure 6 illustrates the different root growth in the subsystems.

The third part of Table 2 shows the summed total weights of the three systems without statistical comparison. With $1244.00 \mathrm{~g}$, AERO produced more than $32 \%$ or $300 \mathrm{~g}$ more wet mass than the DRF and raft, which is almost the total output of a single channel. A similar calculation is given for the total mass of the leaves, where the DRF produced more than a third more leaves each, with $570.6 \mathrm{~g}$. Regarding the total and leaf dry mass, AERO produced between 40 and $50 \%$ more biomass than the DRF and raft.

The last two parts of Table 2 show that AERO and raft had no difference in leaf color, but the DRF showed significant differences to both other systems.

\subsection{Physicochemical Parameters}

The average oxygen concentration during the experiment was $8.3 \mathrm{mg} / \mathrm{L}$ at an oxygen saturation of $101.2 \%$. The development of the temperature and the EC (Electric Conductivity) value is shown in Figure 7. The water temperature was $26.2{ }^{\circ} \mathrm{C}$ at the beginning, dropped to $21.1^{\circ} \mathrm{C}$ over the following 10 days, and stabilized at $27-28^{\circ} \mathrm{C}$ at the end. The average water temperature was $26.0^{\circ} \mathrm{C}$. The conductivity increased steadily from 1530.7 to 
$2780.0 \mu \mathrm{s} / \mathrm{cm}$ during the experiment and averaged $2131.3 \mu \mathrm{s} / \mathrm{cm}$. The mean $\mathrm{pH}$ was 6.4 but was above 7.0 at the beginning, decreased continuously, and was 6.0 at the end. Mean redox potential was $163.5 \mathrm{mV}$ and mean salinity $1.1 \%$. The average room temperature and humidity were $19.9^{\circ} \mathrm{C}\left(\min 8.3^{\circ} \mathrm{C}, \max 30.6^{\circ} \mathrm{C}\right)$ and $40.6 \%(\min 6.8 \%, \max 73.7 \%)$, respectively.

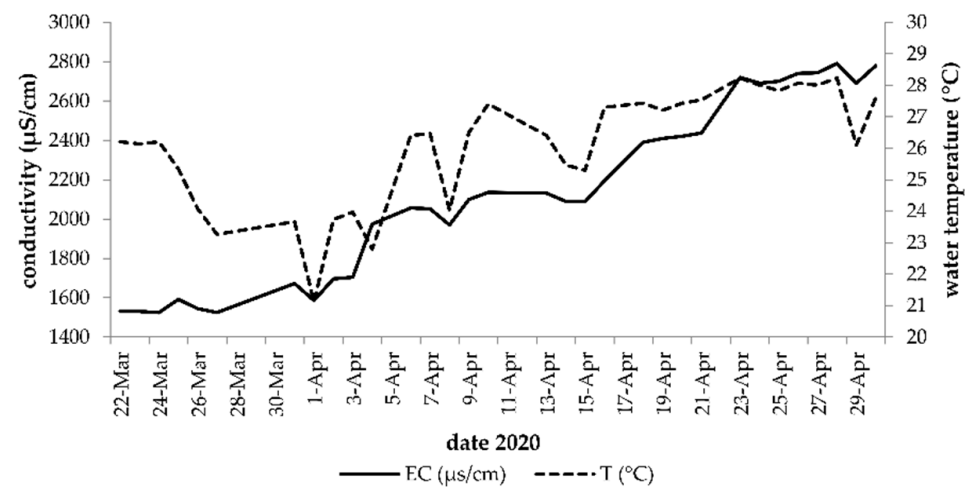

Figure 7. Electric conductivity $(\mu \mathrm{s} / \mathrm{cm})$ and water temperature $\left({ }^{\circ} \mathrm{C}\right)$ increase during the experiment.

The mean nitrate-nitrogen concentration $\left(\mathrm{NO}_{3}{ }^{-}-\mathrm{N}\right)$ was $164.54 \mathrm{mg} / \mathrm{L}$ and nitritenitrogen $\left(\mathrm{NO}_{2}{ }^{-}-\mathrm{N}\right) 0.01 \mathrm{mg} / \mathrm{L}$, which resulted in a concentration of $164.55 \mathrm{mg} / \mathrm{L}$ total oxidized nitrogen (TON). With an ammonium-nitrogen $\left(\mathrm{NH}_{4}{ }^{+}-\mathrm{N}\right)$ concentration of $0.05 \mathrm{mg} / \mathrm{L}$, this results in an average concentration of $164.60 \mathrm{mg} / \mathrm{L}$ of total dissolved nitrogen (TDN). Further nutrient concentrations were: orthophosphate $20.38 \mathrm{mg} / \mathrm{L}$, potassium $11.08 \mathrm{mg} / \mathrm{L}$, magnesium $18.03 \mathrm{mg} / \mathrm{L}$, calcium $262.83 \mathrm{mg} / \mathrm{L}$, iron $0.05 \mathrm{mg} / \mathrm{L}$, and sulfate $49.05 \mathrm{mg} / \mathrm{L}$.

\section{Discussion}

\subsection{Fish Growth}

The African catfish showed very good growth parameters during the experiment. At a feeding rate of $50 \%$ of a commercial fish farm, the FCR values of 1.27 (fish weight class 1; initial weight $1267 \mathrm{~kg}$ ), 1.17 (class 2; $0.839 \mathrm{~kg}$ ), and 0.84 (class 3; $0.043 \mathrm{~kg}$ ) were within the expected range. Comparable values were described in an experiment with $C$. gariepinus and O. basilicum, where a low-protein diet (31\%) resulted in FCRs of 1.11-1.25 and a high-protein diet (40\%) in FCRs of $0.97-1.30$ for fish with initial weights of $81.2 \mathrm{~g}$ and $188.1 \mathrm{~g}$, respectively [15]. At feeding rates of $25 \%$, C. gariepinus showed FCR values of 2.40; $1.43 ; 0.94$ (class $3 ; 2 ; 1$ ) [17], and $2.69 ; 1.23 ; 0.97$ [34], while feeding rates of $80 \%$ resulted in significantly improved FCRs of $0.97 ; 0.87 ; 0.72$ [18], and $0.91 ; 0.84 ; 0.74$ [7]. The good FCR values obtained from $80 \%$ feeding rates were also reported for homogeneous low-weight fish $(83.0 \pm 8.2 \mathrm{~g})$ with an FCR of 0.80 and homogeneous medium-weight (140.2 $\pm 8.7 \mathrm{~g})$, homogeneous heavy-weight $(198.0 \pm 8.1 \mathrm{~g})$, and a heterogeneous group $(139.7 \pm 48.4 \mathrm{~g})$ with FCRs of 0.90 each [35].

The specific growth rate (SGR (\%/day)) of $0.45 ; 0.60 ; 2.37$ (class $1 ; 2 ; 3)$ was also in a good range, confirming that smaller fish grows much faster than larger fish, which have a greater absolute requirement of energy for maintenance [36]. Comparative SGR values were described for fish with a lower initial weight $(365 \mathrm{~g})$ where a $38.7 \%$ protein diet resulted in an SGR of $0.60 \%$ /day and a $31.3 \%$ protein diet in an SGR of $0.40 \%$ /day [37]. The condition factor $(\mathrm{C})$ of $0.83 ; 0.76 ; 0.81$ demonstrates that the fish were proportionally heavier than, for example, at a $25 \%$ feeding rate $(0.70 ; 0.69 ; 0.67)$ under similar conditions [17], and thus were in a better physiological state [38]. The results show that higher feeding rates result in better FCR, SGR, and C values. Under intensive stocked conditions, however, low $\mathrm{pH}$ values and high nutrient loads (higher EC value) can be expected under heavy feeding. 


\subsection{Physicochemical Parameters}

The physical and chemical parameters showed mostly sufficient values for plant growth (Table 1). The water temperature of $26.0 \pm 1.9^{\circ} \mathrm{C}$ was slightly above the optimal value for basil growth of $20.0-25.0^{\circ} \mathrm{C}[16,39]$ but still under the recommended maximum of $30.0{ }^{\circ} \mathrm{C}$ [40]. In principle, the $\mathrm{pH}$ value of $6.4 \pm 0.5$ was also in the upper tolerance range of 5.5-6.5 for soilless culture [40], but it was problematic that the $\mathrm{pH}$ did not remain constant and ranged between 5.92-7.44 during the experiment, thus worsening the availability of some nutrients for the plants $[40,41]$. The electrical conductivity (EC) of $2131.3 \pm 449.5 \mu \mathrm{S} / \mathrm{cm}$ was within a range with good basil yields in hydroponics [42], while recommended EC ranges can greatly differ from 300 to $3100 \mu \mathrm{S} / \mathrm{cm}[43,44]$. However, the EC value was also lowest at the beginning of the experiment, and therefore, lower nutrient concentrations were present. For a more precise analysis of the EC value, the individual nutrient concentrations must be examined; the total dissolved nitrogen (TDN) levels, with $164.60 \mathrm{mg} / \mathrm{L}$ (with nitrogen nitrate $164.54 \mathrm{mg} / \mathrm{L}$ ), calcium $262.83 \mathrm{mg} / \mathrm{L}$, and sulfate $(49.05 \mathrm{mg} / \mathrm{L})$, were in a good or acceptable concentration range [45,46]. The nitrite concentration was $0.01 \mathrm{mg} / \mathrm{L}$ and the ammonium concentration $0.05 \mathrm{mg} / \mathrm{L}$, which indicates that the nitrification process of the aquaculture unit's biofilter worked very well [47]. Furthermore, high nitrate/ammonium ratios, as in this experiment $\left(\mathrm{NO}_{3}{ }^{-}-\mathrm{N} / \mathrm{NH}_{4}{ }^{+}-\mathrm{N}\right.$; 164.54/0.05), have positive effects on plant growth [48]. Acceptable concentrations of phosphate $20.38 \mathrm{mg} / \mathrm{L}$ and magnesium $18.03 \mathrm{mg} / \mathrm{L}$ were present [46], whereby $\mathrm{pH}$ values below 7 may have led to a constant reduction in the availability of these two nutrients [40]. As is often observed in aquaponics, the bottlenecks were mainly potassium with $11.08 \mathrm{mg} / \mathrm{L}$ and iron with $0.05 \mathrm{mg} / \mathrm{L}[17,46]$, which were considerably lower than the recommended ranges of about $262 \mathrm{mg} / \mathrm{L}$ potassium and about $2 \mathrm{mg} / \mathrm{L}$ iron [44]. The too-high $\mathrm{pH}$ value at the beginning of the experiment further worsened the uptake of the too-low iron concentration, leading to, along with the lack of potassium, typical deficiency symptoms, such as yellow coloring of the leaves and even necrosis [49]. Nutrient deficiencies should be strictly avoided, e.g., by using fertilizers, because they make the plants vulnerable to diseases and can considerably reduce the yield [50,51]. The decrease of the $\mathrm{pH}$ value and the simultaneous increase of the electrical conductivity significantly improved the health and appearance of the plants as the experiment proceeded. For professional growth and final evaluation, the experiment should be replicated under commercial conditions with $\mathrm{pH}$ monitoring and sufficient nutrient addition.

\subsection{Plant Growth}

Basil growth showed significant differences in the three hydroponic subsystems. Of the 16 investigated parameters (without colorimeter indexes), aeroponics (AERO) performed significantly better $(p<0.05)$ than the DRF in 11 and better than the raft in 13 parameters (Table 2). The total wet weight (62.20 g) in AERO was 33\% higher than the DRF (46.80 g) and $40 \%$ better than raft $(44.28 \mathrm{~g})$. AERO also produced heavier $(789.33 \mathrm{mg})$, longer $(7.89 \mathrm{~cm})$, and wider leaves $(5.14 \mathrm{~cm})$. This resulted in a total leaf biomass in wet and dry weight of $28.53 \pm 8.74 \mathrm{~g}$ and $4.26 \pm 1.23 \mathrm{~g}$, which, however, was similar in the DRF $(20.19 \pm 6.57 \mathrm{~g} ; 2.83 \pm 0.90 \mathrm{~g})$ and raft $(20.35 \pm 7.14 \mathrm{~g} ; 2.84 \pm 1.04 \mathrm{~g})$. In another herb experiment with valerian (Valeriana officinalis), aeroponics produced less biomass and leaf area than the floating raft and substrate culture systems, whereby it was suspected that the higher proliferation of roots within the frame might have reduced the performance of the nozzles [30]. An aeroponic experiment with sweet basil demonstrated that the plants with less root zone volume at a canal growth depth of $15 \mathrm{~cm}$ and $30 \mathrm{~cm}$ resulted in higher dry biomass production, plant heights, and leaves per plant due to better nutrient availability and uptake compared with a depth of $70 \mathrm{~cm}$ [25]. The results show that limited space inside the aeroponic channels has a decisive effect onto plant growth, but that this space must ensure sufficient nozzle performance in the case of strong root growth. In the present experiment, the relatively small root zone volume within an aeroponic channel with a 
depth and width of $12 \mathrm{~cm}$ each has increased the economically important leaf productivity (wet and dry mass) in AERO by more than $40 \%$ compared to the DRF and raft.

The DRF system showed only two differences to raft in root wet weight and SPAD but otherwise showed almost identical growth. This is best illustrated by the summed total weight (wet; dry) of all individual plants of the respective experimental group, where AERO clearly performed best (1244.00 g; $151.99 \mathrm{~g})$, and the DRF $(935.90 \mathrm{~g} ; 103.95 \mathrm{~g})$ and raft $(929.90 \mathrm{~g} ; 104.10 \mathrm{~g})$ produced almost identical total biomasses (Table 2). In a preliminary experiment during summer, the DRF system performed significantly better than the raft $(82.02 \mathrm{~g} ; 34.94 \mathrm{~g})$ in economically important growth parameters such as total wet weight and leaf mass wet weight $(107.70 \mathrm{~g} ; 45.36 \mathrm{~g})$ at an average water temperature of $28.0 \pm 2.4^{\circ} \mathrm{C}$ with peaks of almost $35.0^{\circ} \mathrm{C}$ [17]. The DRF system was originally developed to maintain root activity during the summer season under high temperatures [21]. However, since the average water temperature of $26.0^{\circ} \mathrm{C}$ cannot be considered too high [21,40], similar growth was expected in the raft and DRF during this experiment. In contrast, the highest SPAD values (chlorophyll content) were found in the DRF (37.00) and AERO (36.58), and both were significantly higher than the raft (33.58). In a basil (Ocimum basilicum) study with different fertilizers, the basil plants in the control group had a SPAD value of 32.02, and the fertilized plants ranged from 35.18-43.87 [52]. Present values show that chlorophyll content of raft was similar to unfertilized plants while the DRF and AERO were comparable to fertilized basil. The aero roots in the DRF and AERO may have altered the plant availability of nitrogen, as chlorophyll is a nitrogen-containing molecule [53].

The total basil length showed no differences in the three systems with just over $70 \mathrm{~cm}$, but it must be considered that AERO has a significantly higher shoot/root ratio with a longer shoot axis $(52.04 \mathrm{~cm})$ and smaller roots $(18.80 \mathrm{~cm})$ than the DRF $(40.81 \mathrm{~cm} ; 29.58 \mathrm{~cm})$ and raft $(42.22 \mathrm{~cm} ; 28.41 \mathrm{~cm})$ (Table 2). At a comparable growth time of 6 weeks, an interim evaluation determined similar plant sizes in an experiment where basil grown in an aquaponic raft system averaged about $53 \mathrm{~cm}$ in height, while basil grown in a hydroponic raft system measured only about $32 \mathrm{~cm}$ [39]. With a considerably longer growth period of 12 weeks, substrate-grown basil (O. basilicum), fertilized with seaweed extracts, had a maximum height of $49.2 \mathrm{~cm}$ (control $46.6 \mathrm{~cm}$ ) [54]. It is noteworthy that despite the roots in AERO being over 50\% shorter than the other two systems, they formed 32\% more dry weight $(1.08 \mathrm{~g})$ compared with the DRF $(0.82 \mathrm{~g})$, and were $61 \%$ heavier than raft $(0.67 \mathrm{~g})$. A closer look at the roots (Figures 4 and 6) reveals that the roots in the AERO system have an altered morphology. Basil grown in soil usually has a central taproot and many horizontally developing hairy roots [55]. The plants grown in the DRF and raft formed a large number of long, thin, fibrous-looking roots instead of a central taproot. In contrast, the AERO roots were strongly fused, which makes the overall appearance much more compact. In addition, the root base showed an increased occurrence of thickened, first-order lateral roots. The main function of lateral roots is anchoring, which increases water uptake and facilitates nutrient extraction [56]. Aeroponics seems to accelerate the plants' ability of first-order lateral root development and rapid root induction, and has therefore repeatedly proven its suitability for the clonal propagation of a wide variety of plants such as tomatoes (Solanum lycopersicum), potatoes (Solanum tuberosum), and peppers (Capsicum spp.), as well as medicinal plants [57-59]. Better root growth was also reported in an experiment with lettuce, in which aeroponics formed a significantly higher root biomass compared with NFT and substrate culture. However, unlike the present experiment, this did not result in increased shoot growth [26]. In contrast, in potato (Solanum tuberosum) seed tuber production, plants in aeroponics had significantly more root vitality, shoot fresh and dry weight, and total leaf area than in aero-hydroponics and deep-water culture [60]. Due to the significantly better basil growth parameters in the AERO system, it can be assumed that the altered root morphology and larger root biomass triggered by the AERO treatment resulted in better nutrient uptake and, thus, in improved growth of the above-ground parts of the plants. Further studies should investigate which other plant species respond with increased shoot growth to the aeroponic treatment. 
Aeroponics is not only capable of inducing enhanced growth in certain plant species, but the technique itself is also superior in terms of disease vulnerability, water, time and space requirements, and large-scale plant production [61]. The biggest challenge for future commercial applications of aeroponics in aquaponics is finding the right balance between the filter stage of the fish process water and the nozzle and droplet size. The herewith utilized original aeroponics system (GHE AeroFlo40 system) had a too-large droplet size and thus could not spray all areas in the AERO channels sufficiently and evenly with the nutrient-enriched process water. Thus, it was modified and tested with different and finer nozzle sizes. If the nozzles are too small, they clog due to the suspended solids in the fish process water, and if the final filter stage is too fine, the filters clog too quickly and require continuous maintenance. Under both scenarios, there is a risk that the roots would dry out due to undersupply. Future research should focus on finding the right balance between the best nozzle and droplet size and economically reasonable filter stages.

\section{Conclusions}

This study investigated the growth of basil (Ocimum basilicum) by using the process water from intensive cultivation of African catfish (Clarias gariepinus) in three hydroponic subsystems: AERO, DRF, and raft. AERO produced shorter but heavier roots in dry weight $(18.80 \mathrm{~cm} ; 1.08 \mathrm{~g})$ compared with the DRF $(29.58 \mathrm{~cm} ; 0.82 \mathrm{~g})$ and raft $(28.41 \mathrm{~cm} ; 0.67 \mathrm{~g})$. AERO also performed better in the growth of the above-ground plant parts, such as shoot axis height $(52.04 \mathrm{~cm})$, than the DRF $(40.81 \mathrm{~cm})$ and raft $(42.22 \mathrm{~cm})$, and also had a $40 \%$ better economically important leaf wet and dry weight $(28.53 \mathrm{~g} ; 4.26 \mathrm{~g}$ ) compared with the DRF (20.19 g; $2.83 \mathrm{~g})$ and raft (20.35 g; 2.84). Total biomass was highest in plants cultured in the AERO hydroponic subsystem in wet and dry weight (1244.00 g; $151.99 \mathrm{~g})$ compared to the DRF (935.90 g; $103.95 \mathrm{~g}$ ) and raft (929.90 g; $104.10 \mathrm{~g})$. Overall, AERO performed significantly better than the DRF and/or raft in 13 of 16 examined parameters, while the DRF and raft were almost identical (AERO $>$ DRF $=$ raft). We suggest that aeroponics is so far underestimated and, due to the outstanding productivity coupled with the resource-saving principle of aquaponics, its application can be considered as a food production system of the future. For the large scale-commercial application of aeroponics in aquaponics (s.s.), the addition of fertilizer is required to cope with deficient potassium and iron. Technologically, future research focus must be placed on finding the best suitable filter systems and nozzle sizes that match the applied fish process water. Floating raft culture systems are particularly suitable for domestic or semi-commercial basil production due to the simple construction, and can be used in areas with no water shortages or where the water use does not result in high operational costs due to the higher water demand. The DRF system is especially useful under high water temperatures and tropical conditions.

Author Contributions: All authors contributed to several aspects of the study, specifically, conceptualization: J.P., U.K., S.A., and H.W.P.; methodology: J.P. and U.K.; software: J.P. and U.K.; validation: J.P., U.K., S.A., and H.W.P.; formal analysis: J.P., U.K., S.A., and H.W.P.; investigation: U.K. and J.P.; resources: J.P.; data curation: J.P., U.K., S.A., and H.W.P.; writing-original draft preparation: J.P., U.K., S.A., and H.W.P.; writing-review and editing: J.P., U.K., S.A., and H.W.P.; visualization: J.P.; supervision: U.K., H.W.P., and S.A.; project administration: H.W.P. and U.K.; funding acquisition: H.W.P. and U.K. All authors have read and agreed to the published version of the manuscript.

Funding: We thank the Ministry of Agriculture, Environment and Consumer Protection of MecklenburgWestern Pomerania (Germany) and the European Union for supporting research in aquaponics. This experiment was funded through the project "Performance and process water management in commercial (integrated) aquaculture systems with African catfish (Clarias gariepinus) in MecklenburgWestern Pomerania" (MV-II.1-LM-007: 139030000103, EMFF: 7302). This project was also funded by the Ph.D Scholarship Programme “Unsere Besten promovieren in Rostock" from the University of Rostock. We acknowledge financial support from Deutsche Forschungsgemeinschaft and Universität Rostock within the funding program Open Access Publishing.

Institutional Review Board Statement: Not applicable. 
Informed Consent Statement: Not applicable.

Data Availability Statement: Not applicable.

Conflicts of Interest: The authors declare no conflict of interest.

\section{References}

1. Palm, H.W.; Knaus, U.; Appelbaum, S.; Goddek, S.; Strauch, S.M.; Vermeulen, T.; Jijakli, M.H.; Kotzen, B. Towards commercial aquaponics: A review of systems, designs, scales and nomenclature. Aquac. Int. 2018, 26, 813-842. [CrossRef]

2. Love, D.C.; Fry, J.P.; Li, X.; Hill, E.S.; Genello, L.; Semmens, K.; Thompson, R.E. Commercial aquaponics production and profitability: Findings from an international survey. Aquaculture 2015, 435, 67-74. [CrossRef]

3. Rakocy, J.E. Aquaponics: Integrating fish and plant culture. Aquac. Prod. Syst. 2012, 1, 343-386.

4. Simon, J.E.; Quinn, J.; Murray, R.G. Basil: A source of essential oils. In Advances in New Crops, 1st ed.; Janick, J., Simon, J.E., Eds.; Timber Press: Portland, OR, USA, 1990; Volume 1, pp. 484-489.

5. Makri, O.; Kintzios, S. Ocimum sp.(basil): Botany, cultivation, pharmaceutical properties, and biotechnology. J. Herbs Spices Med. Plants 2008, 13, 123-150. [CrossRef]

6. Beaman, A.R. Irradiance, Total Nitrogen, and Nitrate-N: Ammonium-N Ratio Requirements for Optimal Edible Biomass Production of Basil. Master's Thesis, Iowa State University, Ames, IA, USA, 2008; p. 64.

7. Knaus, U.; Pribbernow, M.; Xu, L.; Appelbaum, S.; Palm, H.W. Basil (Ocimum basilicum) cultivation in decoupled aquaponics with three hydro-components (grow pipes, raft, gravel) and African catfish (Clarias gariepinus) production in Northern Germany. Sustainability 2020, 12, 8745. [CrossRef]

8. Dunwoody, R.K. Aquaponics and Hydroponics: The Effects of Nutrient Source and Hydroponic Subsystem Design on Sweet Basil Production. Master's Thesis, University of Central Missouri, Warrensburg, MO, USA, 2013.

9. Raimondi, G.; Orsini, F.; Maggio, A.; De Pascale, S.; Barbieri, G. Yield and quality of hydroponically grown sweet basil cultivars. In Proceedings of the I International Symposium on the Labiatae: Advances in Production, Biotechnology and Utilisation, Sanremo, Italy, 30 November 2006; pp. 357-360.

10. Baßmann, B.; Harbach, H.; Weißbach, S.; Palm, H.W. Effect of plant density in coupled aquaponics on the welfare status of African catfish Clarias gariepinus. J. World Aquac. Soc. 2018, 51, 183-199. [CrossRef]

11. FAO.org. Available online: http://www.fao.org/fishery/species/2982/en (accessed on 16 December 2020).

12. Knaus, U.; Wenzel, L.C.; Appelbaum, S.; Palm, H.W. Aquaponics (s.l.) Production of spearmint (Mentha spicata) with African catfish (Clarias gariepinus) in Northern Germany. Sustainability 2020, 12, 8717. [CrossRef]

13. Knaus, U.; Palm, H.W. Effects of fish biology on ebb and flow aquaponical cultured herbs in northern Germany (Mecklenburg Western Pomerania). Aquaculture 2017, 466, 51-63. [CrossRef]

14. Palm, H.W.; Bissa, K.; Knaus, U. Significant factors affecting the economic sustainability of closed aquaponic systems; Part II: Fish and plant growth. AACL Bioflux 2014, 7, 162-175.

15. Pantanella, E. Nutrition and Quality of Aquaponic Systems. Ph.D. Thesis, Universita degli Studi della Tuscia, Viterbo, Italy, 2012.

16. Walters, K.J.; Currey, C.J. Hydroponic greenhouse basil production: Comparing systems and cultivars. HortTechnology 2015, 25, 645-650. [CrossRef]

17. Pasch, J.; Ratajczak, B.; Appelbaum, S.; Palm, H.W.; Knaus, U. Growth of basil (Ocimum basilicum) in DRF, raft, and grow pipes with effluents of African catfish (Clarias gariepinus) in decoupled aquaponics. AgriEngineering 2021, 3, 92-109. [CrossRef]

18. Pasch, J. Einfluss Einer Wurzel-Belüftung auf das Wachstum der Marokkanischen Minze (Mentha spicata L.) bei Drei Berschiedenen Hydroponik-Subsystemen unter Aquaponischer Produktion. Master's Thesis, University of Rostock, Rostock, Germany, 2018.

19. Silva, L.; Gasca-Leyva, E.; Escalante, E.; Fitzsimmons, K.M.; Lozano, D.V. Evaluation of biomass yield and water treatment in two aquaponic systems using the dynamic root floating technique (DRF). Sustainability 2015, 7, 15384-15399. [CrossRef]

20. Silva, L.; Valdés-Lozano, D.; Escalante, E.; Gasca-Leyva, E. Dynamic root floating technique: An option to reduce electric power consumption in aquaponic systems. J. Clean. Prod. 2018, 183, 132-142. [CrossRef]

21. Kao, T.C.; Hsiang, T.; Changhua, R.O.C. The Dynamic Root Floating Hydroponic Technique: Year-Round Production of Vegetables in Roc on Taiwan; ASPAC Food \& Fertilizer Technology Centerz: Changhua, Taiwan, 1991.

22. Buckseth, T.; Sharma, A.K.; Pandey, K.K.; Singh, B.P.; Muthuraj, R. Methods of pre-basic seed potato production with special reference to aeroponics-A review. Sci. Hortic. 2016, 204, 79-87. [CrossRef]

23. Barak, P.; Smith, J.D.; Krueger, A.R.; Peterson, L.A. Measurement of short-term nutrient uptake rates in cranberry by aeroponics. Plant. Cell Environ. 1996, 19, 237-242. [CrossRef]

24. Mbiyu, M.W.; Muthoni, J.; Kabira, J.; Elmar, G.; Muchira, C.; Pwaipwai, P.; Pwaipwai, J.; Otieno, S.; Onditi, J. Use of aeroponics technique for potato (Solanum tuberosum) minitubers production in Kenya. J. Hortic. For. 2012, 4, 172-177.

25. Salachas, G.; Savvas, D.; Argyropoulou, K.; Tarantillis, P.A.; Kapotis, G. Yield and nutritional quality of aeroponically cultivated basil as affected by the available root-zone volume. Emir. J. Food Agric. 2015, 27, 911-918. [CrossRef]

26. Li, Q.; Li, X.; Tang, B.; Gu, M. Growth responses and root characteristics of lettuce grown in aeroponics, hydroponics, and substrate culture. Horticulturae 2018, 4, 35. [CrossRef]

27. NASA. Environmental and Agricultural Resources, progressive plant growing has business blooming. In NASA Spinoff; NASA: New York, NY, USA, 2006; pp. 64-77. 
28. Clawson, J.M.; Hoehn, A.; Stodieck, L.S.; Todd, P.; Stoner, R.J. Re-Examining Aeroponics for Spaceflight Plant Growth; SAE Technical Paper 2000-01-2507; SAE: Toulouse, France, 2000; p. 9.

29. Farran, I.; Mingo-Castel, A.M. Potato minituber production using aeroponics: Effect of plant density and harvesting intervals. Am. J. Potato Res. 2006, 83, 47-53. [CrossRef]

30. Tabatabaei, S.J. Effects of cultivation systems on the growth, and essential oil content and composition of valerian. J. Herbs Spices Med. Plants 2008, 14, 54-67. [CrossRef]

31. Phan-Huy, S.A. Hydroponic products in Switzerland. Agrar Forsch. 1994, 1, 367-370.

32. Microsoft ${ }^{\circledR}$ Corporation. Microsoft Excel ${ }^{\circledR}$, Microsoft ${ }^{\circledR}$ Corporation: Redmond, WA, USA, 2010.

33. IBM Deutschland GmbH. IBM SPSS Statistics for Windows, Version 20.0; IBM Deutschland GmbH: Ehningen, Germany, 2011.

34. Zimmermann, J. Vergleich des Wachstums von Marokkanischer Minze (Mentha spicata) in Drei Verschiedenen Hydroponik Subsystemen unter Aquaponischer Produktion. Master's Thesis, University of Rostock, Rostock, Germany, 2017.

35. Martins, C.I.; Aanyu, M.; Schrama, J.W.; Verreth, J.A. Size distribution in African catfish (Clarias gariepinus) affects feeding behaviour but not growth. Aquaculture 2005, 250, 300-307. [CrossRef]

36. Hepher, B. Nutrition of Pond Fishes; Cambridge University Press: Cambridge, UK, 1988; p. 388.

37. Degani, G.; Ben-Zvi, Y.; Levanon, D. The relationship between body size and growth of African catfish (Clarias gariepinus) (Burchell, 1922) fed practical diet. Indian J. Fish. 1988, 35, 207-210.

38. Anene, A. Condition factor of four Cichlid species of a man-made lake in Imo State, Southeastern Nigeria. Turk. J. Fish. Aquat. Sci. 2005, 5, 43-47.

39. Saha, S.; Monroe, A.; Day, M.R. Growth, yield, plant quality and nutrition of basil (Ocimum basilicum L.) under soilless agricultural systems. Ann. Agric. Sci. 2016, 61, 181-186. [CrossRef]

40. Somerville, C.; Cohen, M.; Pantanella, E.; Stankus, A.; Lovatelli, A. Small-Scale Aquaponic Food Production: Integrated Fish and Plant Farming; FAO Fisheries and Aquaculture Technical Paper No. 589; FAO: Rome, Italy, 2014; p. 262.

41. Saaid, M.F.; Sanuddin, A.; Ali, M.; Yassin, M.S.A.I.M. Automated pH controller system for hydroponic cultivation. In Proceedings of the 2015 IEEE Symposium on Computer Applications \& Industrial Electronics (ISCAIE), Langkawi, Malaysia, 12-14 April 2015; IEEE: New York, NY, USA, 2015; pp. 186-190.

42. Wortman, S.E. Crop physiological response to nutrient solution electrical conductivity and $\mathrm{pH}$ in an ebb-and-flow hydroponic system. Sci. Hortic. 2015, 194, 34-42. [CrossRef]

43. Rakocy, J.E.; Masser, M.P.; Losordo, T.M. Recirculating Aquaculture Tank Production Systems: Aquaponics-Integrating Fish and Plant Culture; SRAC Publication No. 454; Southern Regional Aquaculture Center: Stoneville, MS, USA, 2006; 16p.

44. Morano, G.; Amalfitano, C.; Sellitto, M.; Cuciniello, A.; Maiello, R.; Caruso, G. Effects of nutritive solution electrical conductivity and plant density on growth, yield and quality of sweet basil grown in gullies by subirrigation. Adv. Hortic. Sci. 2017, 31, 25-30.

45. Trejo-Téllez, L.I.; Gómez-Merino, F.C. Nutrient solutions for hydroponic systems. In Hydroponics: A Standard Methodology for Plant Biological Researches, 1st ed.; Asao, T., Ed.; InTech: Rijeka, Croatia, 2012; Volume 1, pp. 1-22.

46. Bittsanszky, A.; Uzinger, N.; Gyulai, G.; Mathis, A.; Junge, R.; Villarroel, M.; Kotzen, B.; Komives, T. Nutrient supply of plants in aquaponic systems. Ecocycles 2016, 2, 17-20. [CrossRef]

47. Tyson, R.V.; Treadwell, D.D.; Simonne, E.H. Opportunities and challenges to sustainability in aquaponic systems. HortTechnology 2011, 21, 6-13. [CrossRef]

48. Frerichs, C.; Daum, D.; Koch, R. Ammonium toxicity-one cause for growth and quality impairments on organic fertilized basil? J. Kult. 2017, 69, 101-112.

49. López-Millán, A.F.; Grusak, M.A.; Abadía, A.; Abadía, J. Iron deficiency in plants: An insight from proteomic approaches. Front. Plant Sci. 2013, 4, 254. [CrossRef] [PubMed]

50. Hafsi, C.; Debez, A.; Abdelly, C. Potassium deficiency in plants: Effects and signaling cascades. Acta Physiol. Plant. 2014, 36, 1055-1070. [CrossRef]

51. Lucena, J.J. Synthetic iron chelates to correct iron deficiency in plants. In Iron Nutrition in Plants and Rhizospheric Microorganisms; Barton, L.L., Abadia, J., Eds.; Springer: Dordrecht, The Netherlands, 2006; pp. 103-128.

52. Teliban, G.C.; Stoleru, V.; Burducea, M.; Lobiuc, A.; Munteanu, N.; Popa, L.D.; Caruso, G. Biochemical, physiological and yield characteristics of red basil as affected by cultivar and fertilization. Agriculture 2020, 10, 48. [CrossRef]

53. Sifola, M.I.; Barbieri, G. Growth, yield and essential oil content of three cultivars of basil grown under different levels of nitrogen in the field. Sci. Hortic. 2006, 108, 408-413. [CrossRef]

54. Elansary, H.O.; Yessoufou, K.; Shokralla, S.; Mahmoud, E.A.; Skalicka-Woźniak, K. Enhancing mint and basil oil composition and antibacterial activity using seaweed extracts. Ind. Crop. Prod. 2016, 92, 50-56. [CrossRef]

55. Ekren, S.; Sönmez, Ç.; Özçakal, E.; Kurttaş, Y.S.K.; Bayram, E.; Gürgülü, H. The effect of different irrigation water levels on yield and quality characteristics of purple basil (Ocimum basilicum L.). Agric. Water Manag. 2012, 109, 155-161. [CrossRef]

56. Teixeira, J.S.; Ten Tusscher, K.H. The systems biology of lateral root formation: Connecting the dots. Mol. Plant 2019, 12, 784-803. [CrossRef] [PubMed]

57. Valle-Echevarria, D.; Angel, R.; Kantar, M.B.; Branca, J.; Moore, S.; Frederiksen, M.K.; Hagen, L.; Hussain, T.; Baumler, D.J. Aeroponic cloning of Capsicum spp. Horticulturae 2019, 5, 30. [CrossRef]

58. Sharma, U.; Barupal, M.; Shekhawat, N.S.; Kataria, V. Aeroponics for propagation of horticultural plants: An approach for vertical farming. Hortic. Int. J. 2018, 2, 443-444. [CrossRef] 
59. Mehandru, P.; Shekhawat, N.S.; Rai, M.K.; Kataria, V.; Gehlot, H.S. Evaluation of aeroponics for clonal propagation of Caralluma edulis, Leptadenia reticulata and Tylophora indica-Three threatened medicinal Asclepiads. Physiol. Mol. Biol. Plants 2014, 20, 365-373. [CrossRef]

60. Chang, D.C.; Park, C.S.; Kim, S.Y.; Lee, Y.B. Growth and tuberization of hydroponically grown potatoes. Potato Res. 2012, 55, 69-81. [CrossRef]

61. Kumari, R.; Kumar, R. Aeroponics: A Review on Modern Agriculture Technology. Indian Farmer 2019, 6, $286-292$. 